\title{
Sustainable Tourism on Red Island Beach Banyuwangi: An Analysis of Rapfish-MDS (Multi- Dimensional Scaling)
}

\author{
Rita Parmawati ${ }^{1}$, Edriana Pangestuti ${ }^{2}$, Wike $^{3}$, Rizha Hardyansah ${ }^{4}$ \\ \{rita_parmawati@ub.ac.id ${ }^{1}$, edriana_fia@ub.ac.id ${ }^{2}$, wike@ub.ac.id ${ }^{3}$, hardyansah.rizha@gmail.com ${ }^{4}$ \} \\ Universitas Brawijaya, Indonesia ${ }^{1,2,3,4}$
}

\begin{abstract}
Tourism is one of the most rapidly growing economic and services sectors in the world. It has prompted several countries to develop and expand their tourism sectors, including Indonesia. Tourism destinations will support an effort towards local and national development of this country. One of the most potential regions for tourism in Indonesia is Banyuwangi regency, with Red Island Beach as one of its tourism destinations. The sustainable development towards Red Island Beach is necessarily significant concerning the destinations as part of the Wonderful Indonesia strategy, especially Sunrise van Java. This study aims to analyze the sustainable development of marine tourism development in Red Island Beach of Banyuwangi regency. This research used Multidimensional Scaling (MDS) approach or RAPFISH to analyzing the sustainable development of tourism destinations. The results were converted into marine tourism index and called as Indeks Keberlanjutan Wisata Bahari (IKBW), that had five dimensions, including ecology, economy, social culture, institutional, and technology and infrastructure dimensions. The result of MDS analysis showed consecutive scores 54.11, $49.34,50.86,58.20$, and 64.61 for ecology, economy, social culture, institutional, and technology and infrastructure dimensions, respectively. The technology and infrastructure dimensions showing the highest score of MDS analysis indicated the development towards this sector is sufficiently sustainable and appropriate. Contrary, the lowest score of MDS analysis was revealed in the economic dimension indicated less sustainability; this dimension is related to the economic growth of the local people in Red Island Beach. The development towards both dimensions needed for the sustainability of Red Island Beach based on the high and low scores on either dimension.
\end{abstract}

Keywords: MDS RAPFISH, Red Island Beach, Sustainable Tourism, Marine Tourism.

\section{Introduction}

Tourism has become one of the most developed sectors in Indonesia and even in the world. So that tourism sector is often used as a tool to improve economy of a country [1]. In Indonesia the tourism sector continues to experience growth, indicated by the amount of foreign exchange from the tourism sector which continues to increase from 12.23 billion dollars in 2015 to 19.29 billion dollars in 2018 [2]. Tourism development can encourage the economy of a region, and this is due to the development of tourism has a close relationship with economic growth, both economic growths caused by tourism growth and vice versa. So, it is often said that tourism is a bidirectional sector [3][4]. 
The number of foreign tourists visits also increased from 2017 by 14.04 million trips to 15.81 million trips, an increase of $12.58 \%$. The increased number of tourists will also increase GDP (Gross Domestic Product), create jobs, and strengthen the Indonesian economy [1]. It causes the government as the holder of the power make tourism area planning in Indonesia, namely KSPN (National Strategic Tourism Area) and KSPP (Provincial Strategic Tourism Area). East Java Province has several KSPPs, one of which located in Banyuwangi Regency. Banyuwangi Regency Medium-term Development Plan (RPJMD) 2016-2019 states that the tourism sector is planned to support the development of the Regency economy, tourism development in Banyuwangi Regency is carried out with the Diamond Triangle concept in the concept of WPP (Tourism Development Area). Banyuwangi Regency has three WPPs, namely WPP I (a type of tourism based on forest area for adventure and had a natural scenery), WPP II (a type of tourist attraction in coastal waters and low accessibility), and WPP III (an area with tourist objects that have unique resources natural).

Red Island Beach Tourism is one of the tours listed in WPP III in Banyuwangi Regency. Red Island Beach Tourism classified as marine tourism located in a coastal area. Tourism in the coastal area is one of the fastest-growing types of tourism in the tourism industry. Still, in practice, it can be a driver of damage or protection depends on the surrounding community [5]. According to Clarke [6], marine tourism is a highly developed tourism today, but in its development marine tourism also has a high impact on ecosystems. It is because precisely the area is sensitive and complex. During this time the management of the Red Island Beach tourism object in the Banyuwangi district is managed by the surrounding community by forming the Red Island beach Working Group (LWG). Managers conducted by LWG in collaboration with the Department of Perhutani, so that the development of the potential of the Red Island Beach attractions optimize activities oriented to the strength of private capital of the community and local community self-help.

The fact that marine tourism is one of the types of tourism that is developing with its location in the coastal area makes the sustainability of this tour questionable. Also, the rapid and uncontrolled development of tourism in coastal area makes the ecosystem increasingly vulnerable to environmental changes, so the purpose of this study is to analyze the sustainability of marine tourism development on Red Island Beach, Banyuwangi Regency.

\section{Research Methods}

\subsection{Study Area}

This research conducted in Red Island Beach Tourism Banyuwangi District (Figure 1). Red Island Beach located in Pancer Hamlet, Sumberagung, Pesanggaran, Banyunwangi Regency which is a $3 \mathrm{~km}$ long coastal area that has a type of white sand and has a hill as high as 300 meters not far from its beach seedlings. Tourist activities that can be done on Red Island Beach include surfing, snorkeling, fishing, climbing the hill, watching the sunset, and relaxing. Also, the supporting facilities in the surrounding areas classified as complete, such as the control tower, information boards, dining areas, large parking lots, prayer rooms, toilets, and homestays.

\subsection{Data Collection}


MDS is adapted to five main objectives: ecological dimension, economic dimension, socio-cultural dimension, institutional dimension, technological and infrastructure dimensions. The MDS method will provide a regional development strategy through in-depth identification of the indicator objects. In this research, a preliminary study was conducted to determine the indicators for the sustainability dimensions of Red Island Beach (Table 2). The sample was determined by purposive sampling method (50 respondents) with Participatory Rapid Appraisal (PRA) approach. The process of respondent development held by snowball sampling method. The Likert scale used on five levels which states the categories and ratings measured (table 1).

Table 1. Likert Scale Rating

\begin{tabular}{ccc}
\hline Answer Choice & Score & Answer Meaning \\
\hline A & 5 & Strongly agree \\
B & 4 & Agree \\
C & 3 & Neutral \\
D & 2 & Disagree \\
E & 1 & Strongly disagree \\
\hline
\end{tabular}

The Descriptive analysis used to determine the description of the respondents measured from several indicators in question. Interview results are analyzed descriptively and in-depth so that it can support the meaning of the results of research in quantitative.

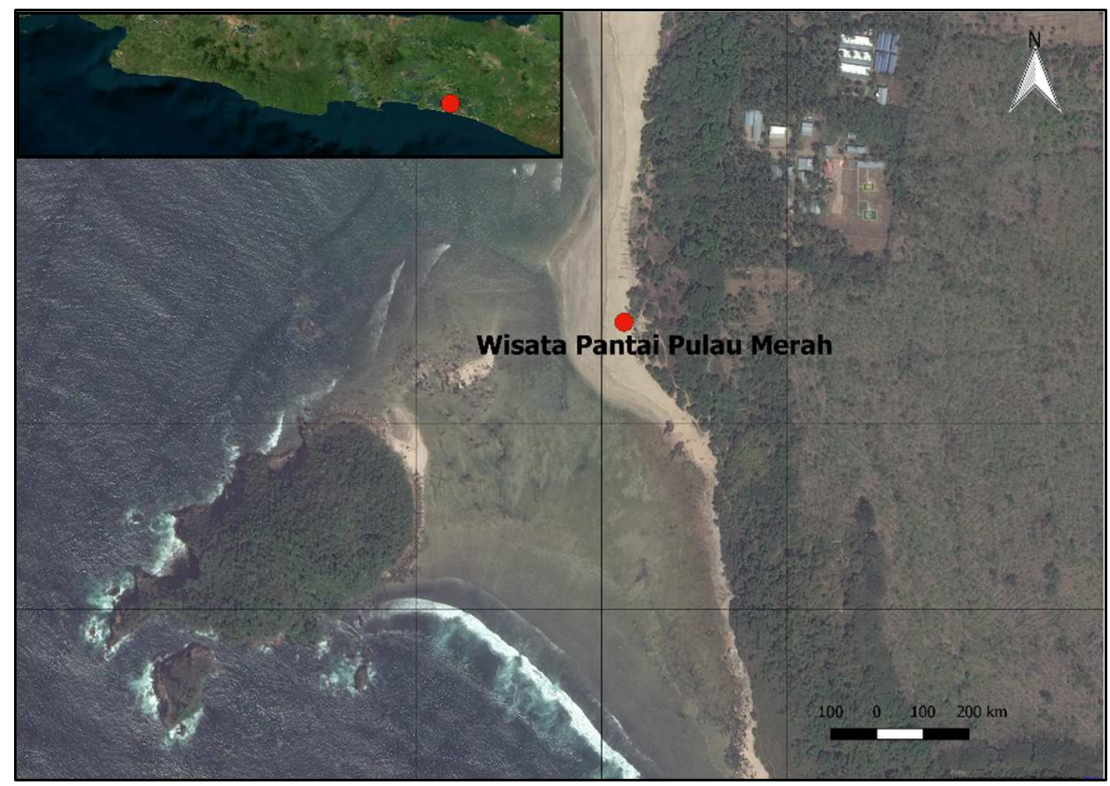

Fig. 1. Marine tourism of Red Island Beach Banyuwangi Regency.

\subsection{Data Analysis}


Analysis of the sustainability of the development of marine tourism in Red Island Beach, Banyuwangi District, was carried out using a Multi-Dimensional Scaling (MDS) approach called RAPFISH [7]. Analysis of the sustainability of the development of marine tourism on the Red Island Beach done through an analysis of the estimation of the sustainability index value of the five dimensions, namely (1) Ecological Dimensions, (2) Economic Dimensions, (3) Socio-Cultural Dimensions, (4) Institutional Dimensions, and (5) Dimensions Technology and Infrastructure. The results of the analysis of the five dimensions obtained as many as 39 attributes, namely seven attributes of Ecological Dimensions, eight attributes of Economic Dimensions, nine attributes of Social Dimensions, eight attributes of Institutional Dimensions, and seven attributes of Technology and Infrastructure Dimensions. Each attribute that has compiled and filled with the existing data condition is then analyzed using MDS, then the sustainability index of each dimension is obtained. Values for the five dimensions analyzed will indicate the sustainability of the development of marine tourism on the Red Island Beach with a value range of $0-100 \%$. There are several categories, namely $0-24.99$, which means bad or unsustainable, 25-49.99, which means less sustainable, 50-74.99, which means quite sustainable, and 75-100, which means excellent or sustainable [8][9].

Table 2. Dimensions and indicators variable

\begin{tabular}{|c|c|}
\hline $\begin{array}{l}\text { Ecological } \\
\text { Dimension }\end{array}$ & $\begin{array}{l}\text { X11 Control of the number of visitors adjusted to the carrying capacity of the } \\
\text { environment. } \\
\text { X12 Supporting facilities built in the development of marine tourism do not } \\
\text { damage the environment of the Red Island beach area. } \\
\text { X13 There is a waste management system around the public facilities of Red Island } \\
\text { beach tourism area. } \\
\text { X14 The location of marine tourism development in Red Island Beach is a place } \\
\text { that is prone to natural disasters (floods and landslides). } \\
\text { X15 Community efforts to protect the environment around attractions and their } \\
\text { ecosystems so that they are sustainable. } \\
\text { X16 Community efforts to preserve the environment by limiting activities that } \\
\text { damage the environment. } \\
\text { X17 The community supports every environmental conservation activity on Red } \\
\text { Island Beach (tree planting). }\end{array}$ \\
\hline $\begin{array}{l}\text { Economic } \\
\text { Dimension }\end{array}$ & $\begin{array}{l}\text { X21 The existence of the Red Island beach marine tourism has an impact on } \\
\text { increasing the economic activities of the surrounding community. } \\
\text { X22 The impact of the Red Island beach marine tourism on the availability of } \\
\text { employment for the surrounding community. } \\
\text { X23 The existence of the Red Island beach marine tourism opens opportunities for } \\
\text { the community to open a business (trading, food stalls, and lodging). } \\
\text { X24 The existence of the Red Island beach marine tourism opens the opportunity } \\
\text { for people to make souvenirs. } \\
\text { X25 The existence of the Red Island beach marine tourism opens opportunities for } \\
\text { people to open businesses in the service sector. } \\
\text { X26 The income of the community around the Red Island beach marine tourism } \\
\text { has increased due to the presence of marine tourism. } \\
\text { X27 The income of the community can be used to meet the needs of daily life with } \\
\text { the marine tourism of Red Island beach. } \\
\text { X28 Income obtained from opening a business in the presence of the Red Island } \\
\text { beach marine tourism constitutes additional income. }\end{array}$ \\
\hline $\begin{array}{l}\text { Socio-cultural } \\
\text { Dimensions }\end{array}$ & $\begin{array}{l}\text { X31 The standard of living of the people in the Red Island Beach area is } \\
\text { increasing. } \\
\text { X32 The community plays an active role in planning, implementing and evaluating }\end{array}$ \\
\hline
\end{tabular}




\begin{tabular}{l|l}
\hline & the activities of the Red Island Beach marine tourism development activities. \\
X33 Remember that public education in the Red Island Beach area is increasing. \\
X34 Cultural heritage and tradition are still preserved by the community to support \\
the development of the Red Island Beach marine tourism. \\
X35 Local residents' values (mutual cooperation, honest and wise attitude) support \\
the development of the Red Island Beach marine tourism. \\
X36 Community entrepreneurial skills are increasing. \\
X37 Communities are given the opportunity to actively identify, process and sell \\
tourism products and services that are specific to their environment. \\
X38 Income obtained from opening a business in the presence of the Red Island \\
beach marine tourism constitutes additional income. \\
X39 There are opportunities given by the community by providing knowledge so \\
that the community can be independent.
\end{tabular}

\section{Result and Discussion}

Based on MDS analysis result using RAPSIFH for five dimensions (ecology, economy, social-cultural, institutions, technology and infrastructure) that support the sustainable marine tourism development on Red Island Beach, various index values were obtained. Furthermore, the five dimensions visualized by the kite diagram in Figure 2. 


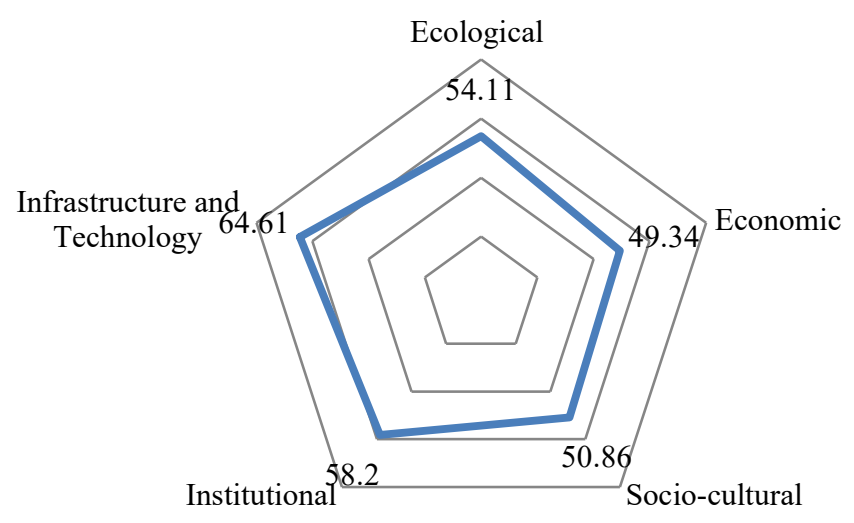

Fig. 2. Kite diagram of sustainability in Red Island Beach.

The kite diagram showed that the ecological dimension has an index value of $54.11 \%$ which means it is quite sustainable, the economic dimension has an index value of $49.34 \%$ which means it is less sustainable, the socio-cultural dimension has an index value of $50.86 \%$ which means it is quite sustainable, the dimension the institutional index has a value of $58.20 \%$ which means it is quite sustainable, the technological and infrastructure dimensions have an index value of $64.61 \%$ which means it is quite sustainable. Therefore, the sustainability development status of Red Island Beach is quite sustainable, with an index value of $55.42 \%$. However, it requires development and improvement for each attribute in each dimension so that the development of Red Island Beach becomes more sustainable. In addition to attributes that considered sensitive to sustainability, the dimensions have also been supported so as not to decrease This is because tourism activities have a significant impact on environmental changes in sensitive and vulnerable coastal areas [10], many changes occur in the central regions of the coastal area to become a means of supporting tourism [11]. Although these coastal and marine resources provide facilities for tourism activities, there is a need to focus on the practical concern of environmental protection if the area will continue to function as a viable resource for alternative tourism [12].

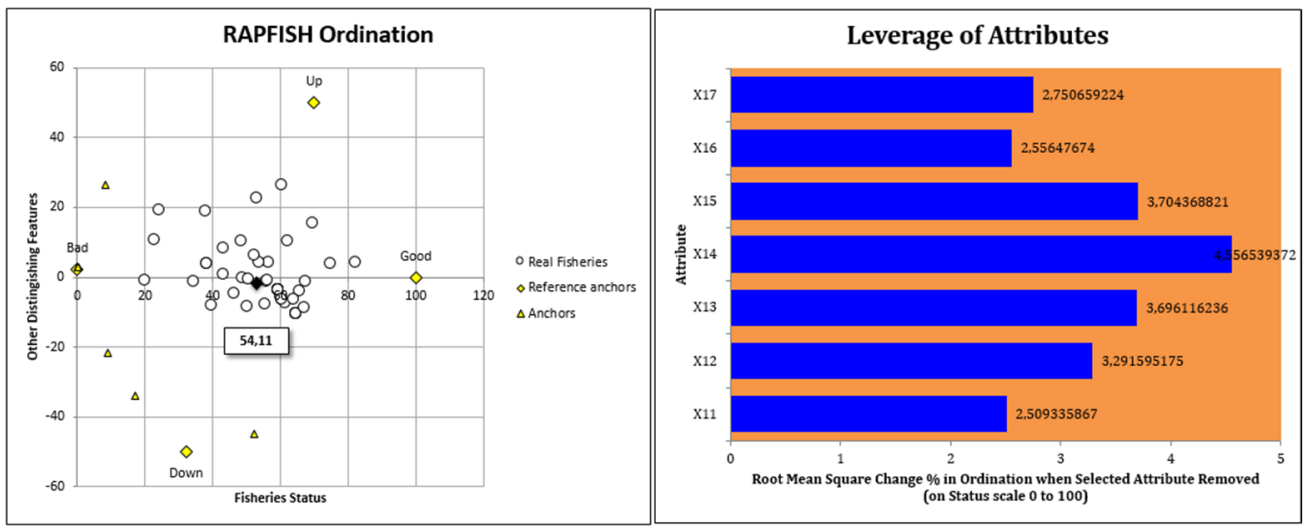

Fig. 3. Rapfish and Leverage of Ecological Dimension 
The result of leverage factor analysis showed that ecological dimensions attribute that has more effect on the decrease and increase of development sustainability of marine tourism on Red Island Beach; It is that the Red Island Beach was a vulnerable place to natural disasters (floods and landslides) with a value of 4, 56. According to the National Disaster Management Plan 2010-2014 from BNPB (National Disaster Management Agency), Banyuwangi Regency is included in one of the districts that have the potential to experience natural disasters such as earthquakes, tsunamis, forest fires, and bad weather. Red Island Beach and Pancer Beach are areas that are prone to earthquakes and tsunamis because they have a flat topography [13].

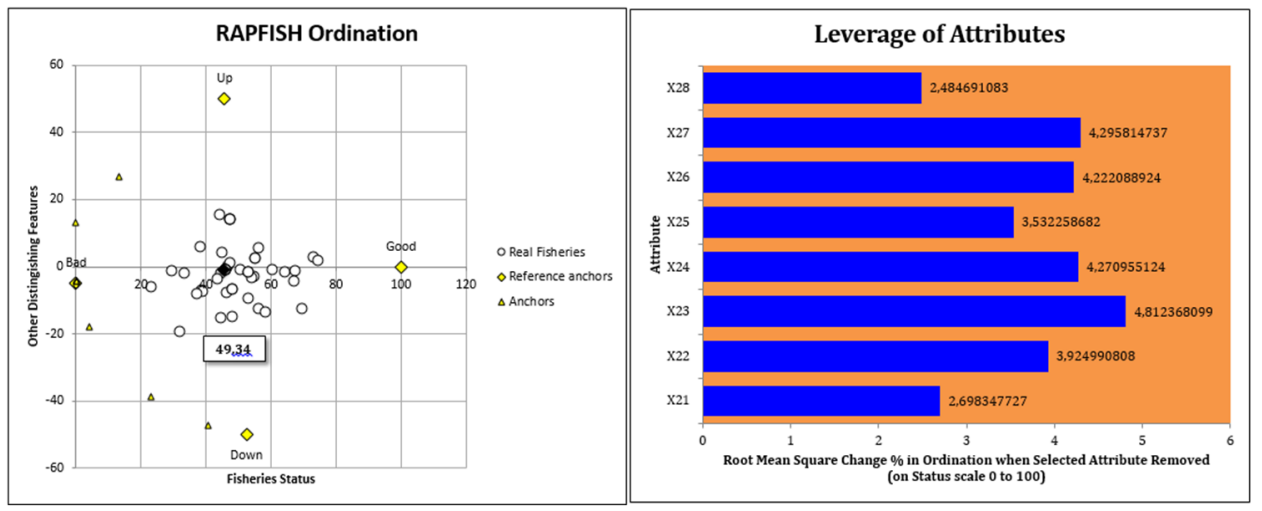

Fig. 4. Rapfish and Leverage of Economic Dimension.

The result of leverage factor analysis showed that economic dimensions attribute that most influences on the decrease and increase the status of sustainability are the attribute X23 (The existence of the Red Island beach marine tourism opens the opportunity for the community to open a business (trading, food stalls, and lodging) with a value of 4.8. Tourism not only will improve the economy of a region, but also can open new jobs, especially for women, teenagers, and other disadvantaged people. This is because the majority of tourism support jobs require not so many skills and are very significant in reducing poverty [14]. Tourism support businesses opened by the community can increase the time of visits by tourists, both local and foreign. The residence time of tourists will increase desire to spend more money to buy something, which is it affects the expenditure of tourists [15] and indirectly will strengthen the economy of the surrounding community who open businesses. 

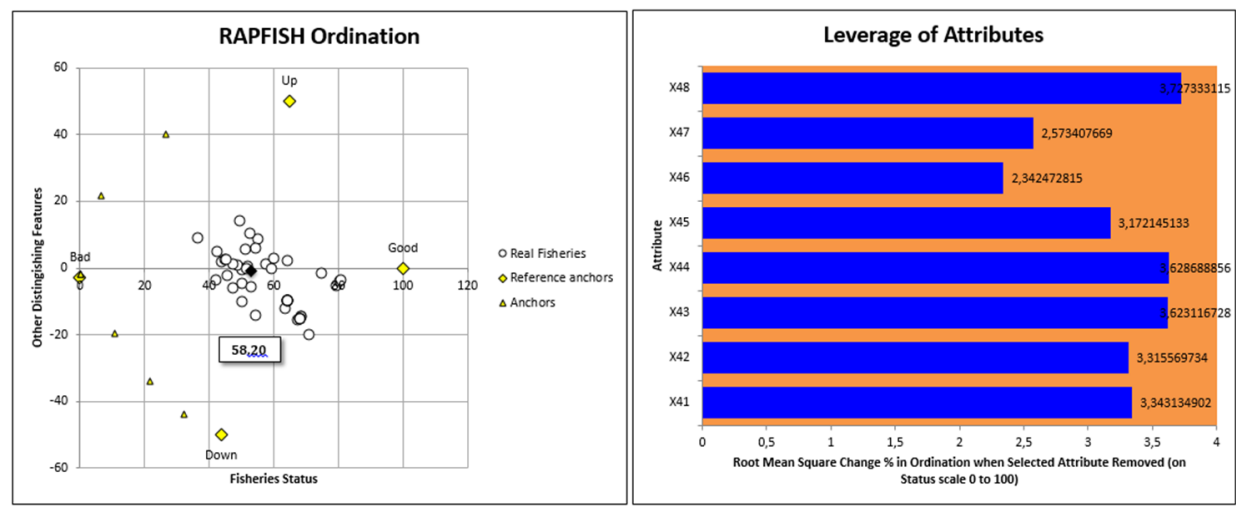

Fig. 5. Rapfish and Leverage of Institutional Dimension.

The result of leverage factor analysis showed institutional dimension has an attribute that most influenced the decrease and increase in the status of sustainability were X48 attributes (Building partnerships between communities through local organizations with tour operators, and the Tourism Office to market and promote marine tourism products in Red Island Beach) with a value of 3.7. Maintaining the sustainability of Red Island Beach, it is necessary to have partnerships and cooperation between the community, as well as related agencies, the private sector, and others. There are four components that must be implemented by the government namely agreement, commitment, control, and cooperation [12].
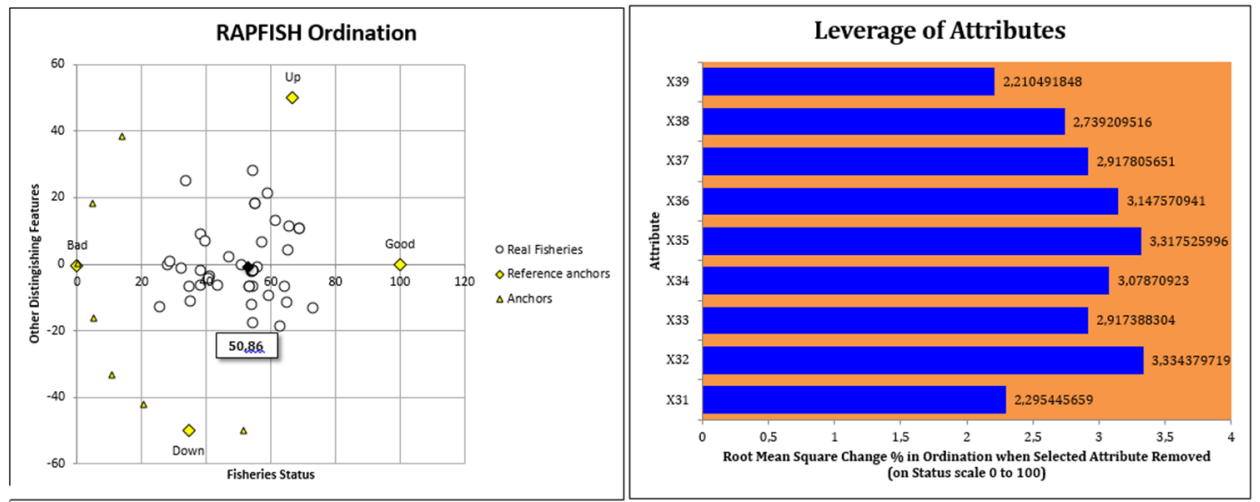

Fig. 6. Rapfish and Leverage of Socio-cultural Dimensions.

The result of leverage factor analysis showed that there is an attribute affecting the sociocultural dimension reduction and improvement of the sustainability status. The attribute is X32 (The community plays an active role in planning, implementing and evaluating the activities of the Red Island Beach marine tourism development) with a value of 3.3. Community participation and cooperation between communities become an essential role in the development and sustainability of tourist areas, research conducted by Parmawati et al [16], states that factors that can be the strength of a tourist destination arise due to the desire and participation of the community to develop their region. 


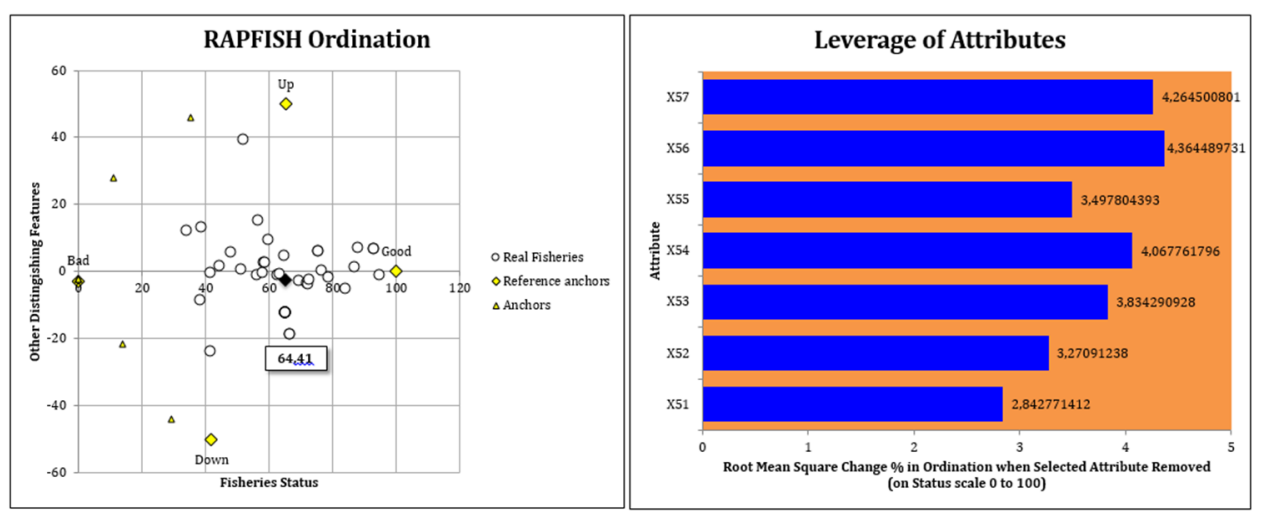

Fig. 7. Rapfish and Leverage of Technology and Infrastructure Dimensions.

The result of leverage factor analysis showed there is an attribute affecting the dimensions of technology and infrastructure and has an influence on the reduction and improvement in the status of sustainability are the attributes X57 (The existence of a homestay with complete facilities with WIFI access) with a value of 4.3. Supporting tourism infrastructure is increasingly becoming one of the factors of a person's desire to go to tourist sites and as a factor in the development of tourist destinations, and the attraction of tourist attractions and service facilities is very influential on the satisfaction of tourists [17][18]. Homestay is one of the leading tourist attractions because it can provide the sensation of living in a quiet nature away from the urban crowd and can enjoy many local traditions and cultural performances [19]. So that homestay is not only about selling and renting lodging but also buying living habits from the local community [20]. Also, homestays become tourism products that can help overcome socioeconomic, political, ethnic, and gender disparities [21].

The synergy between dimensions can support sustainability of Marine Tourism on Red Island Beach. It can be done by optimizing the dimensions that are already quite sustainable and overcome the dimensions that are still less sustainable. Particularly in less sustainable economic dimension, there is something that can be done, it is to optimize the existing resources, namely dragon fruit, which is pushed to new tourist destinations, namely dragon fruit picking tourism. Strengthening the community as a local community is something that must be done, cooperating in planning, monitoring, and evaluation activities, as well as promotional activities for tourist destinations [22][23]. Dimensions that are already quite sustainable such as ecology, socio-culture, institutions, and technology and infrastructure, must be optimized.

\section{Conclusion}

The level of sustainability of Marine Tourism in Red Island Beach Banyuwangi Regency showed a quite sustainable value for four dimensions, such as ecological dimension, institutional dimension, socio-cultural dimension, and technological and infrastructure dimensions. But for the economic dimension was less sustainable. This showed that there were must still be an appropriate solution to overcome the lack of sustainability in economic dimension, and fot the other dimensions must be furthered optimized. 


\subsection{Acknowledgments}

The authors thank the Banyuwangi Regency authorities for research permission. The authors also thank the Red Island Beach management for assistance and research permission. Special thanks to Rizha Hardyansah, Titis Sfabrila Karira, Fajar Rasidii Hidayat.

\section{References}

[1] J. Mariyono, "Determinants of demand for foreign tourism in Indonesia," J. Ekon. Pembang., vol. 18, no. 1, pp. 82-92, 2017.

[2] Badan Pusat Statistik (BPS), Statistik Indonesia 2019. Jakarta: Badan Pusat Statistik, 2019.

[3] R. Othman and N. H. M. Salleh, "Analisis hubungan pembangunan industri pelancongan dan pertumbuhan ekonomi: perbandingan pasaran antara bangsa," J. Ekon. Malaysia, vol. 44, no. 2010, pp. 93-100, 2010.

[4] N. Sak and K. Karymshakov, "Relationship between tourism and economic growth: A panel Granger causality approach," Asian Econ. Financ. Rev., vol. 2, no. 5, p. 591, 2012.

[5] S. Zahedi, "Tourism impact on coastal environment," WIT Trans. Built Environ., vol. 99, pp. 45-57, 2008.

[6] A. C. Clarke, "Towards a future maritime policy for the union: a european vision fot ethe oceans and seas," Rev. del Inst. Naveg. España publicación técnica Cuatrimest. Naveg. marítima, aérea, Espac. y Terr., no. 26, pp. 34-61, 2006.

[7] T. J. Pitcher and D. Preikshot, "RAPFISH: a rapid appraisal technique to evaluate the sustainability status of fisheries," Fish. Res., vol. 49, no. 3, pp. 255-270, 2001.

[8] A. Fauzi and Z. Anna, "Modeling of Fisheries and Marine Resources," Gramedia. Jakarta [Indonesian], 2005.

[9] S. B. Susilo, "Keberlanjutan pembangunan pulau-pulau kecil: Studi kasus kelurahan pulau Panggang dan pulau Pari, kepulauan seribu, DKI Jakarta," Disertasi. Progr. Pascasarj. Inst. Pertan. Bogor. Bogor. 233hlm, 2003.

[10] F. Sakellariadou, "Marine Tourism Development and Sustainability, Case Study The Saronicos Gulf Marinas."

[11] Y. Yeung, "Coastal mega-cities in Asia: transformation, sustainability and management," Ocean Coast. Manag., vol. 44, no. 5-6, pp. 319-333, 2001.

[12] L. M. Marafa and K. C. Chau, "Framework for sustainable tourism development on coastal and marine zone environment," Tour. Leis. Glob. Chang., vol. 1, no. 1, pp. 1-11, 2016.

[13] S. Sunarto and M. A. Marfai, "Potensi Bencana Tsunami dan Kesiapsiagaan Masyarakat Menghadapi Bencana Studi Kasus Desa Sumberagung Banyuwangi Jawa Timur," in Forum Geografi, 2012, vol. 26, no. 1, pp. 17-28.

[14] International Labour Organization, Implications of the Global Economic Crisis for Tourism Employment: Case Study for Indonesia. Jakarta: International Labour Organization, 2009.

[15] G. Athanasopoulos and R. J. Hyndman, "Modelling and forecasting Australian domestic tourism," Tour. Manag., vol. 29, no. 1, pp. 19-31, 2008.

[16] R. Parmawati, R. Imaniyah, L. E. Rokani, M. I. Rajaguni, and A. S. Kurnianto, "Ecotourism Development Strategy of Bukit Jaddih Karst, Madura," J. Indones. Tour. Dev. Stud., vol. 6, no. 2, p. 113, 2018

[17] J. Swarbrooke and S. Horner, Business travel and tourism. Routledge, 2012.

[18] E. R. Aprilia, S. Sunarti, and E. Pangestuti, "Pengaruh daya tarik wisata dan fasilitas layanan terhadap kepuasan wisatawan di Pantai Balekambang Kabupaten Malang," J. Adm. Bisnis, vol. 51, no. 2, pp. 16-21, 2017.

[19] S. A. Jamal, N. Othman, and N. M. N. Muhammad, "Tourist perceived value in a communitybased homestay visit: An investigation into the functional and experiential aspect of value," $J$. Vacat. Mark., vol. 17, no. 1, pp. 5-15, 2011. 
[20] H. Tucker and P. Lynch, "Host-guest dating: The potential of improving the customer experience through host-guest psychographic matching," J. Qual. Assur. Hosp. Tour., vol. 5, no. 2-4, pp. 11-32, 2005.

[21] B. P. Acharya and E. A. Halpenny, "Homestays as an alternative tourism product for sustainable community development: A case study of women-managed tourism product in rural Nepal," Tour. Plan. Dev., vol. 10, no. 4, pp. 367-387, 2013.

[22] P. Russell, "Community-based tourism.," Travel Tour. Anal., no. 5, pp. 89-116, 2000.

[23] S. Selin, "Collaborative alliances: New interorganizational forms in tourism," J. Travel Tour. Mark., vol. 2, no. 2-3, pp. 217-227, 1994. 